\title{
PERSEPSI WAJIB PAJAK TERHADAP CITRA PERPAJAKAN INDONESIA SETELAH FENOMENA KASUS KORUPSI PAJAK
}

\author{
Dian Purnama Sari \\ Universita Katolik Widya Mandala Surabaya \\ Jalan Kalisari Selatan No.1, Kec. Mulyorejo, Surabaya , Jawa Timur - 60112 \\ E-Mail:dian-ps@ukwms.ac.id
}

\section{Akuntansi Bisnis dan Manajemen (ABM),}

Volume 27

Nomor 1

Halaman 15-28

Bulan April, Tahun 2020

ISSN 0854-4190

E-ISSN 2685-3965

\section{Informasi Artikel}

Tanggal Masuk:

25 Februari 2020

Tanggal Revisi:

4 Maret 2020

Tanggal Diterima:

5 April 2020

\section{Abstract}

This study aims to understand the perception of taxpayers after corruption cases involving tax officials in Indonesia. This research uses Mixed Method. Beginning with the PLS test which shows that perceptions of taxpayers have a negative effect on taxpayer obedience. Furthermore, phenomenology is used to further reveal taxpayer compliance. The result there are 3 understandings, namely (1) The image of Indonesian taxation has deteriorated, such as "has fallen on the stairs"; (2) The phenomenon of corruption cases by tax officials opens the eyes of taxpayers and impacts the behavior of taxpayers; and (3) Understanding that Tax, between the state and God. This study also shows that the perception of the Indonesian people about the world of taxation before the existence of corruption cases has been bad and after the emergence of corruption cases taxpayers are increasingly open to the world of Indonesian taxation. A bad perception does not necessarily make taxpayers disobedient, because taxpayers still have the desire to follow the orders of the State and God.

Keywords: Perception; tax payer; Gayus Tambunan; mixed method

\begin{abstract}
Abstrak
Pengelitian ini bertujuan utuk memahami persepsi wajib pajak setelah kasus korupsi yang melibatkan petugas pajak di Indonesia. Penelitian ini menggunakan mixed method. Diawali dengan uji PLS yang menunjukkan bahwa persepsi wajib pajak berpengaruh negatif terhadap kepatuhan dan ketaatan wajib pajak. Selanjutnya digunakan fenomenologi untuk mengungkap lebih jauh tentang kepatuhan wajib pajak. Hasil nya terdapat 3 pemahaman, yaitu (1) Citra perpajakan Indonesia memburuk, seperti "sudah jatuh tertimpa tangga"; (2) Fenomena kasus korupsi dari petugas pajak membuka mata wajib pajak dan berdampak pada perilaku wajib pajak; dan (3) Pemahaman bahwa Pajak, antara negara dan Tuhan. Penelitian ini juga menunjukkan bahwa persepsi masyarakat Indonesia mengenai dunia perpajakan sebelum adanya kasus korupsi telah buruk dan setelah muncul kasus korupsi wajib pajak semakin terbuka terhadap dunia perpajakan Indonesia. Persepsi yang buruk tidak lantas membuat wajib pajak tidak patuh dan tidak taat, karena wajib pajak masih memiliki keinginan untuk mengikuti perintah Negara dan Tuhan.
\end{abstract}

Kata Kunci: Persepsi; Wajib Pajak; Gayus Tambunan; Metode Campuran 


\section{PENDAHULUAN}

Dunia perpajakan di Indonesia telah mengalami banyak perubahan. Perubahanperubahan tersebut meliputi hukum dan aturan perpajakan sampai pada pembenahan institusi serta pelayanan perpajakan itu sendiri. Saat ini, wajah perpajakan Indonesia telah dipoles sedemikian rupa sehingga dapat menarik hati setiap Warga Negara Indonesia untuk rajin dan taat untuk menjalankan kewajibannya dalam membayar pajak. Motto “Lunasi Pajaknya, Awasi Penggunaannya” juga semakin melekat sebagai tanda kejujuran terhadap penggunaan pajak. Perpajakan Indonesia kembali hidup dan menjadi salah satu fokus dalam program pemerintah. Pemerintah juga tidak tanggungtanggung dalam menghidupkan kembali dunia perpajakan Indonesia. Berbagai fasilitas juga ditawarkan bagi Wajib Pajak yang setia dan jujur dalam membayar pajak, misalnya tax amnesty yang menuai banyak pujian di tahun 2016 dan 2017. Namun, di tengah melonjaknya "polesan wajah" perpajakan di Indonesia, korupsi tetap membayangi denyut nadi pemerintahan, termasuk dalam masalah pajak. Kasus korupsi yang melibatkan petugas pajak di Indonesia masih banyak terjadi.

Dimulai dengan kasus Gayus Tambunan yang meledak pada Bulan April 2010 telah mencoreng wajah dunia perpajakan Indonesia (Lumbanrau, 2016). Lubang ini belum tertutup, namun terus ditemukan kembali kasus-kasus korupsi yang melibatkan petugas pajak. Contohnya, tahun 2018 pada bulan Oktober, ditangkapnya Kepala Kantor Pelayanan Pajak (KPP) Pratama Ambon dan 2 petugas lainnya karena menerima suap dari Wajib Pajak untuk mengurangi tagihan pajaknya (Mohammad, 2018). Tak kalah seru, tahun 2019 juga ditangkap empat orang pegawai DJP karena diduga menerima suap untuk menyetujui pengajuan restitusi pajak suatu badan (Ramadhan, 2019) yang disebut-sebut dilakukan oleh bos dealer mobil mewah. Kasuskasus korupsi petugas pajak (Lumbanrau, 2016) tentu menimbulkan pesepsi bagi masyarakat Indonesia, khususnya Wajib Pajak.

Wajib Pajak merupakan individu-individu yang aktif dalam dunia perpajakan Indonesia. Seorang Wajib Pajak memiliki hak dan kewajiban dalam perpajakan. Sesuai sistem pemungutan pajak yang dianut oleh Negara Indonesia, yaitu self assessment system, maka Wajib Pajak-lah yang diberikan wewenang, kepercayaan dan tanggungjawab untuk menghitung, memperhitungkan, membayar dan melaporkan sendiri besarnya pajak yang harus dibayar. Karena itu, kepatuhan dan ketaatan Wajib Pajak kepada peraturan perpajakan serta kejujuran merupakan hal yang penting dengan sistem yang dianut di Indonesi. Diri Wajib Pajak-lah yang banyak berperan dalam kehidupan pajak individualnya. Ketaatan dan kejujuran menjadi hal penting dalam penuaian hak dan kewajiban dalam perpajakan.

Telah banyak penelitian mengenai kepatuhan wajib pajak. Kepatuhan wajib pajak diteliti dari variabel pengetahuan pajak, pemahaman pajak, sunset policy, tax amnesty, sanksi pajak, kesadaran wajib pajak, pelayanan fiskus, kemauan wajib pajak, persepsi atas efektivitas pelayanan, otomatisasi perpajakan, lingkungan wajib pajak, tarif pajak dan masih banyak lagi (Susanti, Dewi dan Sufiyati (2017); Mahfud, Arfan dan Abdullah (2017); Wiyarni, Hartini dan Djuharni (2018); Cahyani dan Noviari (2019); Yusro dan Kiswanto (2014); Vionita dan Kristanto (2018)). Penelitian-penelitian di atas lebih banyak menganalisis faktor-faktor yang mempengaruhi kepatuhan wajib pajak. 
Namun, masih jarang penelitian yang menghubungkan persepsi dengan kepatuhan wajib pajak.

Para Wajib Pajak di Indonesia juga tentu tidak akan melewatkan fenomena kasus korupsi petugas pajak. Fenomena ini tentu meninggalkan bekas di hati dan pikiran para Wajib Pajak serta membentuk persepsi di benak setiap Wajib Pajak. Karena itu, penelitian ini ingin memahami persepsi Wajib Pajak terhadap dunia perpajakan Indonesia setelah kasus korupsi petugas pajak. Tujuan dari penelitian ini adalah untuk mengetahui perubahan persepsi Wajib Pajak terhadap dunia perpajakan Indonesia setelah kasus-kasus korupsi petugas pajak.

\section{KAJIAN PUSTAKA}

\section{Persepsi: Pandangan Subyektif dalam Diri Manusia}

Persepsi menurut Kamus Bahasa Indonesia (1995) dalam Hermansyah dkk (2009) adalah tanggapan (penerimaan) langsung dari sesuatu, atau merupakan proses seseorang mengetahui beberapa hal melalui panca inderanya. Robbins (2003), menyatakan bahwa persepsi didefinisikan sebagai suatu proses dengan mana individuindividu mengorganisasikan dan menafsirkan kesan indera mereka agar memberi makna pada lingkungan mereka. Menurut Schiffman and Kanuk (1994) dalam Hermansyah dkk (2009), persepsi merupakan salah satu faktor psikologis selain motivasi, belajar kepribadian dan sikap. Persepsi sendiri merupakan proses memilih, mengorganisir, dan menginterpretasikan stimuli ke dalam gambaran yang mempunyai arti dan masuk akal sehingga dapat dimengerti. Persepsi timbul karena adanya stimuli dari luar yang akan menekan syaraf sensorik seseorang dan melalui panca indera, stimulus tersebut diseleksi, diorganisir oleh setiap konsumen dengan cara tersendiri.

Menurut Robin (1996) dalam Djasmoredjo (2004), mendefinisikan persepsi sebagai suatu proses yang digunakan individu-individu untuk mengatur dan menginterpretasikan kesan-kesan sensori mereka supaya member makna terhadap lingkungannya. Berdasarkan beberapa pengertian di atas, persepsi memang merupakan pandangan dari dalam diri individu terhadap sesuatu berdasarkan faktor eksternal. Secara sadar maupun tidak sadar, persepsi seseorang akan mempengaruhi keputusan dan tindakan yang diambil oleh seseorang. Persepsi muncul akibat faktorfaktor yang masuk ke dalam psikologis individu dan akan merasuk di dalam pikiran individu tersebut. Inilah yang menyebabkan persepsi mampu mempengaruhi tindakan individu.

\section{Perpajakan Indonesia}

Pajak, menurut Undang-Undang Nomor 28 tahun 2007 pasal 1 mengenai Ketentuan Umum dan Tata Cara Perpajakan, merupakan kontribusi wajib kepada Negara yang terutang oleh orang pribadi atau badan yang bersifat memaksa berdasarkan Undang-Undang dengan tidak mendapatkan imbalan secara langsung dan digunakan untuk keperluan Negara bagi sebesar-besarnya kemakmuran rakyat. Direktorat Jenderal Pajak (DJP) selalu berusaha untuk memberikan citra yang positif kepada masyarakat, mulai dari slogan, tatacara penerimaan Wajib Pajak di Kantor Pajak dan sebagainya. DJP juga memberikan berbagai kemudahan kepada wajib pajak untuk melakukan pembayaran dan pelaporan. Namun, citra perpajakan Indonesia masih tercoreng akibat oknum-oknum yang menggunakan kekuasaanya yang 
berhubungan dengan perpajakan. Penelitian ini berusaha untuk mengetahui persepsi wajib pajak terhadap citra perpajakan Indonesia, terutama setelah fenomena kasus korupsi pegawai pajak.

\section{METODE PENELITIAN}

\section{Metode Triangulasi: Gerakan Metodologis Ketiga}

Metode triangulasi mulai ramai diperbincangkan sejak munculnya penelitian kualitatif yang dipandang sebagai tandingan dan reaksi terhadap metodologi penelitian kuantitatif yang dominan sepanjang dua dasawarsa terakhir abad XX (Tashakkori dan Teddlie, 2010). Rancangan metode triangulasi juga memasukkan beragam teknik dari tradisi kuantitatif sekaligus kualitatif sambil memadukan keduanya secara unik untuk menjawab berbagai permasalahan penelitian. Menurut Raharjo (2010), triangulasi pada hakikatnya merupakan pendekatan multimetode yang dilakukan peneliti pada saat mengumpulkan dan menganalisis data. Ide dasarnya adalah bahwa fenomena yang diteliti dapat dipahami dengan baik sehingga diperoleh kebenaran tingkat tinggi jika didekati dari berbagai sudut pandang. Memotret fenomena tunggal dari sudut pandang yang berbeda-beda akan memungkinkan diperoleh tingkat kebenaran yang handal. Karena itu, triangulasi ialah usaha mengecek kebenaran data atau informasi yang diperoleh peneliti dari berbagai sudut pandang yang berbeda dengan cara mengurangi sebanyak mungkin bias yang terjadi pada saat pengumpulan dan analisis data.

Norman K. Denkin yang diungkap oleh Raharjo (2010) mendefinisikan triangulasi sebagai gabungan atau kombinasi berbagai metode yang dipakai untuk mengkaji fenomena yang saling terkait dari sudut pandang dan perspektif yang berbeda. Sampai saat ini, konsep Denkin ini dipakai oleh para peneliti kualitatif di berbagai bidang. Menurutnya, triangulasi meliputi empat hal, yaitu: (1) Triangulasi metode yang dilakukan dengan cara membandingkan informasi atau data dengan cara yang berbeda, (2) Triangulasi antar-peneliti yang dilakukan dengan cara menggunakan lebih dari satu orang dalam pengumpulan dan analisis data, (3) Triangulasi sumber data yaitu menggali kebenaran informasi tertentu melalui berbagai metode dan sumber perolehan data, dan (4) Triangulasi teori yang dapat meningkatkan kedalaman pemahaman asalkan peneliti mampu menggali pengetahuan teoretik secara mendalam atas hasil analisis data yang telah diperoleh.

Penelitian ini akan menggunakan triangulasi metode, yaitu membandingkan hasil metode kuantitatif dengan metode kualitatif demi memastikan keakuratan hasil penelitian. Penelitian ini menggunakan metode kuantitatif dengan menyebarkan kuisioner dan mengolahnya dengan menggunakan alat uji statistik, yaitu Partial Least Square (PLS). Analisis PLS adalah teknik statistika multivariate yang melakukan pembandingan antara variabel dependen berganda dan variabel independen berganda (Jogiyanto dan Abdillah, 2009). Metode penelitian kualitatif dilakukan dengan menggunakan metode fenomenologi. Fenomenologi merupakan pandangan berpikir yang menekankan kepada pengalaman-pengalaman subjektif manusia dan interpretasi-interpretasi dunia (Khairin, 2008). Metoda fenomenologi bertujuan 
memahami respon atas keberadaan manusia/masyarakat serta pengalaman yang dipahami dalam berinteraksi (Saladien, 2006 dalam Izza dan Hamzah, 2009).

Pada hakikatnya, penelitian kualitatif adalah penelitian yang bermaksud untuk memahami fenomena tentang apa yang dialami oleh subyek penelitian, misalnya perilaku, persepsi, motivasi, tindakan, dan sebagainya, secara holistik dan dengan cara deskripsi dalam bentuk kata-kata dan bahasa pada suatu konteks khusus yang alamiah dan dengan memanfaatkan berbagai metode ilmiah Moleong (2005). Karakter khusus riset kualitatif terutama adalah berupaya mengungkapkan keunikan individu, kelompok, masyarakat dan atau organisasi tertentu dalam kehidupan sehari-hari. Pendekatan ini merupakan suatu metode penelitian yang diharapkan dapat menghasilkan suatu deskripsi tentang ucapan, tulisan atau perilaku yang dapat diamati dari suatu individu, kelompok, masyarakat, dan atau organisasi tertentu dalam suatu setting tertentu pula. Kasus "Gayus Tambunan" memang telah menjadi fenomena baru di masyarakat. Hampir seluruh masyarakat Indonesia yang "melek" informasi pasti pernah mendengar nama Gayus Tambunan dan menimbulkan berbagai pendapat di masyarakat. Berdasarkan jalan pemahaman metodologi ketiga ini, pemahaman persepsi masyarakat, khususnya Wajib Pajak, terhadap dunia perpajakan Indonesia setelah kasus Gayus Tambunan diharapkan dapat menemukan langkah awal penemuan-penemuan berikutnya.

\section{Sumber Data dan Teknik Pengumpulan Data}

Pada penelitian ini, sumber data berasal dari hasil kuisioner, catatan hasil wawancara dengan informan, pendalaman latar belakang informan, catatan hasil pengamatan serta dokumen-dokumen yang mungkin masih terkait dengan penelitian ini. Informan merupakan orang yang bersedia untuk memberikan informasi mendalam yang diperlukan dalam penelitian ini. Menurut Sutopo (2003), sumber data yang sangat penting dalam penelitian kualitatif adalah manusia yang menjadi narasumber atau informan. Untuk mengumpulkan informasi dari sumber data ini diperlukan teknik penyebaran kuisioner dan wawancara mendalam.

Pemilihan informan yang tepat sangat mendukung keberhasilan penelitian ini. Karena itu, informan yang dipilih dalam penelitian ini adalah seorang Wajib Pajak yang memiliki Nomor Pokok Wajib Pajak (NPWP), memperoleh penghasilan lebih dari satu pemberi kerja untuk melihat kepatuhan, ketaatan dan kejujuran Wajib Pajak serta bersedia memberikan informasi sejujur-jujurnya kepada peneliti dengan jaminan bahwa peneliti tentu tidak akan memberikan informasi tersebut kepada siapapun. Mempertimbangkan kriteria, metode penelitian dan keterbatasan waktu, maka informan yang terpilih dalam penelitian ini berjumlah 12 orang Wajib Pajak. Para Wajib Pajak ini dipilih karena kerterbukaan informasi mengenai persepsi mereka terhadap citra dunia perpajakan Indonesia.

Untuk memperoleh data primer, sebagai tahap awal, peneliti akan melakukan metode survei terlebih dahulu untuk melengkapi data secara kuantitatif. Tahapan kedua, peneliti melakukan wawancara tidak terstruktur yang dilakukan seperti bincang-bincang biasa untuk mengetahui informasi yang dimiliki informan tentang apa yang ingin diketahui oleh peneliti. Wawancara tidak terstruktur, sering pula disebut wawancara mendalam, dilakukan dalam suasana tidak formal dan dengan 
pertanyaan yang mengarah pada kedalaman informasi. Wawancara ini dilakukan berulang sesuai dengan kebutuhan peneliti yang berkaitan dengan kejelasan dan kemantapan informasi yang diberikan. Kedalaman informasi yang diinginkan diperoleh melalui wawancara yang mendalam dan hal ini dilakukan dalam situasi akrab agar wawancara tersebut tidak terkesan sebagai sebuah aktivitas interogasi yang menyebabkan informasi tidak turun sepenuhnya. Tahap yang ketiga adalah pengumpulan dokumen-dokumen yang terkait apabila dibutuhkan.

\section{HASIL DAN PEMBAHASAN}

\section{Jalan Awal Pencarian: Alat Uji Statistik Partial Least Square (PLS)}

Model penelitian kuantitatif dalam penelitian ini akan dianalisis dengan menggunakan alat uji statistika Partial Least Square (PLS) dengan model penelitian sebagai berikut:

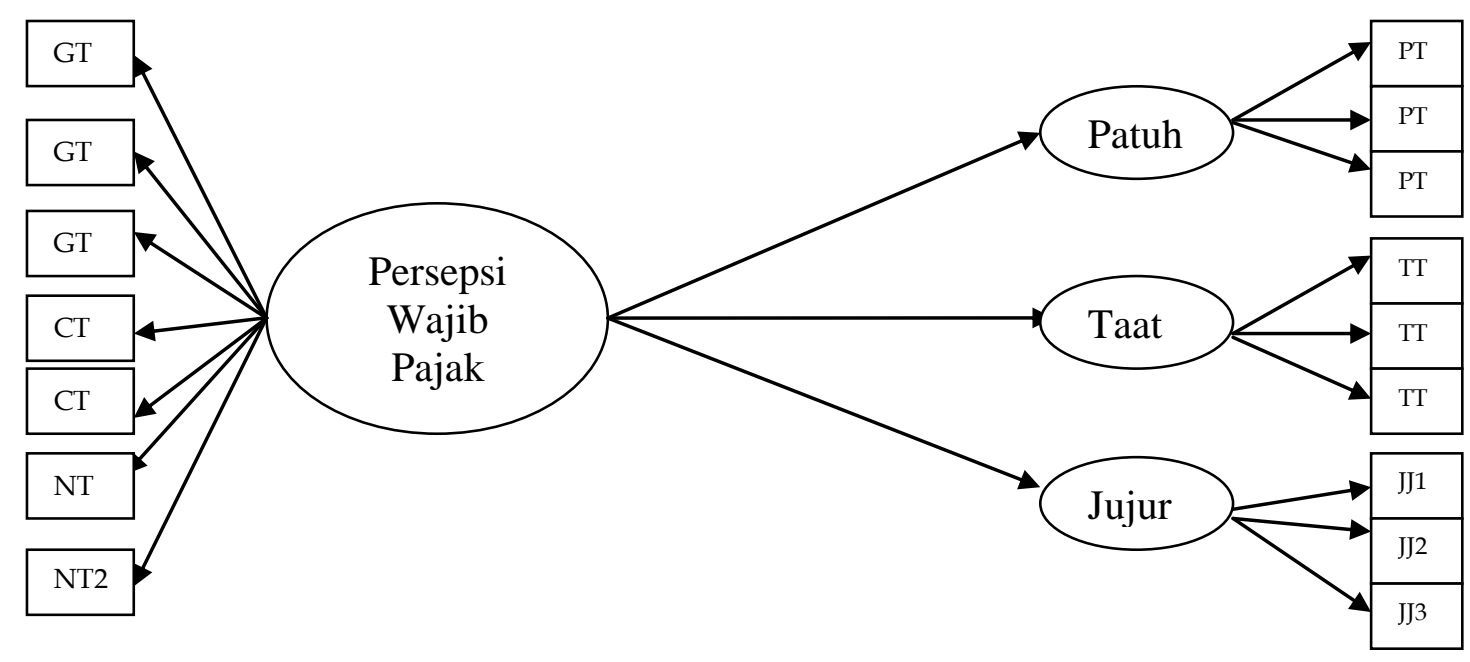

\section{Gambar 1. Model Penelitian dengan menggunakan PLS}

Dari model di atas dapat terlihat bahwa penelitian ini akan melihat persepsi Wajib Pajak terhadap dunia perpajakan Indonesia. Variabel independen $(X)$ adalah persepsi Wajib Pajak dan variabel dependen $(Y)$ adalah dunia perpajakan Indonesia yang diukur melalui variabel patuh, taat dan jujur. Variabel independen akan diukur melalui kategori-kategori pertanyaan, yaitu yang berhubungan dengan Kasus-kasus korupsi petugas pajak (GT), Citra (CT) dan Niat Wajib Pajak (NT). Variabel dependen (Y) yaitu dunia perpajakan Indonesia, akan diproksikan dengan kepatuhan Wajib Pajak terhadap peraturan UU Perpajakan (PT, contohnya kepatuhan dalam pelaporan dan penyetoran pajak dan sebagainya), ketaatan Wajib Pajak terhadap peraturan UU Perpajakan (TT, contohnya ketaatan dalam penggunaan norma, besar PTKP dan sebagainya) serta kejujuran Wajib Pajak dalam melaporkan penghasilannya (JJ). Data diperoleh melalui metode survei. 
Dari hasil alat uji statistika dengan menggunakan SmartPLS versi 1.01, maka diperoleh hasil sebagai berikut:

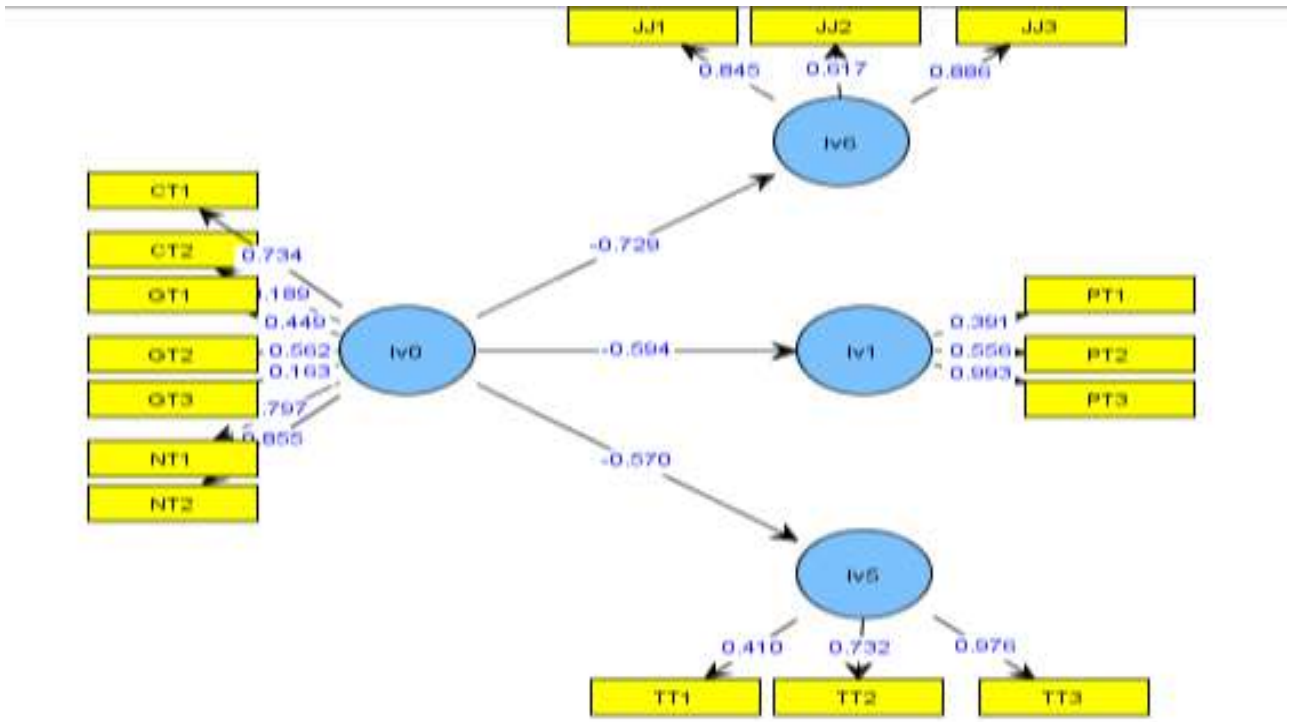

Gambar 2. Hasil Uji PLS terhadap Model Penelitian

Setelah melakukan uji statistik dengan menggunakan SmartPLS versi 1.01, maka diketahui bahwa model penelitian ini valid dan realibel. Namun, bagi variabel Kepatuhan Wajib Pajak (lv1) dinyatakan tidak valid, baik uji validitas konvergen dan uji validitas diskriminan. Variabel Kepatuhan Wajib Pajak tidak valid karena nilai Average Variance Extracted (AVE) lebih rendah dari 0,5, yaitu 0,483 serta nilai akar AVE lebih rendah dari nilai Correlations of the latent variables, yaitu 0,695 terhadap 0,993. Karena itu Kepatuhan Wajib Pajak (lv1) tidak digunakan dalam pengujian ini.

Variabel Ketaatan Wajib Pajak (lv5) dan Kejujuran Wajib Pajak (lv6) dinyatakan valid dan realibel sehingga dapat digunakan dalam penelitian ini. Valid dapat dilihat dari nilai AVE Ketaatan Wajib Pajak (lv5) dan Kejujuran Wajib Pajak (lv6), yaitu sebesar 0,553 dan 0,627 yang berada di atas 0,5 serta akar AVE yang lebih tinggi dari nilai Correlations of the latent variables. Realibel untuk variabel Ketaatan Wajib Pajak (lv5) dan Kejujuran Wajib Pajak (lv6) dilihat melalui nilai Composite reliability, yaitu 0,770 dan 0,831 yang lebih tinggi dari 0,7 sehingga dikatakan realibel.

Dari uji validitas dan reabilitas, maka model dapat dilanjutkan untuk memprediksi hubungan kausal antar variabel. Hasil Gambar 2 menunjukkan bahwa korelasi hubungan antara Persepsi Wajib Pajak (lv0) kepada Ketaatan Wajib Pajak (lv5) adalah sebesar -0,570. Korelasi hubungan antara Persepsi Wajib Pajak (lv0) kepada Kejujuran Wajib Pajak (lv6) adalah -0,729. Dengan melihat nilai T-Statistik, diperoleh hasil yang signifikan untuk masing-masing hubungan variabel karena Ketaatan Wajib Pajak (lv5) dan Kejujuran Wajib Pajak (lv6) masing-masing memiliki nilai 6,557 dan 10,916 yang lebih besar dari 1,96. Hubungan korelasi tersebut menunjukkan bahwa variabel persepsi Wajib Pajak memiliki korelasi negatif terhadap ketaatan Wajib Pajak dan kejujuran Wajib Pajak secara signifikan. Hal ini menunjukkan apabila persepsi 
Wajib Pajak semakin dipengaruhi oleh kasus korupsi petugas pajak, maka ketaatan dan kejujuran Wajib Pajak akan semakin rendah.

\section{Jalan Setapak Pemahaman Melalui Fenomenologi dalam Fenomena "Korupsi Petugas Pajak"}

Secara kualitatif, model penelitian akan dilakukan dengan penelitian ini menggunakan paradigma interpretif. Alat analisis yang digunakan adalah fenomenologi. Kasus Gayus Tambunan, disadari maupun tidak telah menjadi fenomena yang cukup ekstrem di kalangan masyarakat. Nyatanya, fenomena ini masih terus berlanjut hingga sekarang. Data diperoleh melalui pengamatan kata-kata dan tindakan informan yang didapat secara langsung (sumber primer) yang terekam baik melalui pencatatan maupun dengan alat-alat elektronik. Kemudian, penulis melengkapi data dengan menggunakan data tambahan, seperti dokumen-dokumen. Dokumen yang mungkin dibutuhkan, misalnya catatan keuangan Wajib Pajak, SPT Wajib Pajak dan sebagainya.

Setiap Wajib Pajak Indonesia tentu memiliki persepsi yang berbeda-beda dalam melihat dunia perpajakan Indonesia. Menurut uji statistika diperoleh hasil bahwa semakin persepsi Wajib Pajak dipengaruhi kasus korupsi petugas pajak, maka ketaatan dan kejujuran Wajib Pajak akan semakin rendah. Pengaruh ini menarik untuk dikaji lebih lanjut, karena fenomena ini telah mampu merasuk ke dalam pikiran dan hati para Wajib Pajak dalam persepsi mereka dan berujung pada tindakan.

\section{Pemahaman pertama: Citra Dunia Perpajakan Indonesia Ibarat Sudah Jatuh Tertimpa Tangga}

Dunia perpajakan Indonesia sedang berbenah. Hal itu mungkin yang sering terlintas saat kita melihat berbagai spanduk dan iklan yang ditampilkan oleh pemerintah, dalam hal ini Direktorat Jenderal Pajak, berusaha menonjolkan transparansi dan kegunaan pajak bagi masyarakat Indonesia. Slogan "Lunasi Pajaknya, Awasi Pengunaannya" tentu sudah tidak asing di telinga kita. Hasil dari penggunaan pajak juga diproklamirkan, seperti program-program kesehatan bagi rakyat yang tidak mampu, sekolah gratis bagi siswa-siswi tidak mampu dan sebagainya. Berbagai cara digunakan oleh Direktorat Jenderal Pajak yang telah mengalami masa keterpurukan sejak jaman Orde Baru. Namun, apakah semua jalan yang telah ditempuh oleh Direktorat Jenderal Pajak telah mampu mengubah paradigma buruk dunia perpajakan Indonesia di mata para Wajib Pajaknya?

Banyak dari Wajib Pajak ternyata belum "goyah" dengan janji-janji manis Direktorat Jenderal Pajak. Citra dunia perpajakan Indonesia yang buruk tetap melekat dalam benak Wajib Pajak di Indonesia. Salah satu informan dengan jelas menyatakan "Dari dulu sebelum kasus korupsi-korupsi itu muncul, persepsi terhadap perpajakan di Indonesia memang sudah negatif". Pernyataan tersebut dengan gamblang menunjukkan bahwa citra perpajakan Indonesia dalam pandangan Wajib Pajak Indonesia belum mengalami perbaikan. Mayoritas informan menyatakan hal yang senada. Pendapat yang lebih ekstrem tercermin dari pendapat berikut ini "Sebelumnya saya sudah punya citra buruk pada lembaga ini (Lembaga Perpajakan di Indonesia). Rahasia umumlah kalau lembaga ini merupakan lahan basah untuk mengeruk 
keuntungan dan menimbun kekayaan". Ataupun pendapat lain yang menyatakan, "Sebelum kasus korupsi-korupsi petugas e sudah tidak terlalu percaya pada pemerintah termasuk mengenai pengelolaan pajaknya". Secara mayoritas pendapat yang disampaikan oleh informan memang mencerminkan persepsi mereka yang memang sudah buruk sedari awal, bahkan sebelum adanya kasus korupsi petugas pajak. Para informan percaya bahwa dunia perpajakan Indonesia memang sulit untuk dipercaya "kebersihannya". Bahkan secara ekstrem menyebutkan bahwa perpajakan Indonesia merupakan "lahan basah" dalam artian merupakan tempat yang mudah untuk mengeruk keuntungan dan menimbun kekayaan secara halal maupun tidak.

Upaya-upaya perbaikan yang disampaikan oleh lembaga perpajakan Indonesia rupanya tidak mampu membentuk citra yang lebih baik bagi dunia perpajakan Indonesia sekarang ini. Salah satu informan menyatakan, "Persepsi awal sudah buruk. Lalu muncul kasus korupsi besar-besar pada saat sistem perpajakan yang sedang berbenah. Kasus ini jelas menjadi batu sandungan dalam proses perbaikan itu". Upaya yang diupayakan lembaga perpajakan yang dibangun dengan tertatih-tatih menjadi hancur kembali. Masyarakat tidak dapat menerima upaya perbaikan perpajakan namun malah berbalik ke selera asal, yaitu persepsi yang negatif. Salah satu informan juga menyebutkan, "Karena adanya kasus korupsi petugas pajak, banyak orang yang berpikir negatif dengan petugas pajak yang lain". Pendapat ini menyiratkan bahwa masyarakat selain tidak menerima kesan yang baik terhadap upaya perbaikan malah ditambah dengan kecurigaan terhadap petugas pajak lainnya. Kondisi citra dunia perpajakan Indonesia ibarat "Sudah jatuh tertimpa tangga". Kondisi dunia perpajakan yang sedang mencoba untuk merangkak dan berdiri, dijatuhkan dengan adanya kasus korupsi petugas pajak yang tentu menyeret nama-nama "teman" petugas pajak yang lain.

\section{Pemahaman kedua: Fenomena "Gayus Tambunan" Membuka Mata dan Sikap}

Sebelum kasus Gayus Tambunan terkuak, dunia "mafia" dalam perpajakan Indonesia seakan tertutup rapat. Selama ini masyarakat hanya berusaha mengendusendus "bau busuk" dunia perpajakan tanpa memperoleh kenyataan yang terbuka secara gamblang di depan mata. Namun, kasus "Gayus Tambunan" seakan menyuguhkan kenyataan yang selama ini hanya menjadi kasak-kusuk dalam masyarakat. Terlebih dengan banyaknya kasus-kasus korupsi petugas pajak yang semajkin terkuak. Salah satu informan menyebutkan bahwa kasus korupsi petugas pajak membuat masyarakat semakin tahu dan jelas bagaimana fakta yang terjadi di dalam perpajakan Indonesia sekarang ini maupun yang kemarin-kemarin. Praktikpraktik "mafia" pajak akhirnya terungkap dan menjadi buah bibir di masyarakat. Berbagai bukti dan fakta yang terbuka telah mampu menyadarkan masyarakat untuk membuka mata dalam menyaksikan drama demi drama "kebusukan" dunia perpajakan Indonesia.

Fakta-fakta semakin banyak terungkap. Salah satu informan menyatakan, "Kasus Gayus semakin membuka wawasan bahwa banyak penyelewengan yang terjadi dalam pengelolaan pajak". Apa yang selama ini hanya terlihat samar-samar menjadi terbuka dengan jelas. Berbagai penyelewengan dalam pengelolaan pajak yang selama ini tidak diketahui oleh masyarakat umum terbuka dengan jelas. Salah satu informan menyatakan bahwa dirinya semakin yakin bahwa perpajakan di Indonesia bisa 
'diatur'. Meskipun sebelum kasus-kasus korupsi petugas pajak terungkap, sang informan telah mencurigai adanya pengaturan tersebut, namun sebelum ada bukti yang jelas, beliau juga tidak berani untuk mengambil kesimpulan pasti. Tetapi didukung dengan fakta-fakta dari fenomena "Gayus Tambunan", sang informan berani untuk menyatakan kenyakinannya mengenai "pengaturan" dalam dunia perpajakan Indonesia.

Fenomena "Gayus Tambunan" sampai pada titik memberikan pengaruh kepada masyarakat. Salah satu informan menyatakan, "Untuk apa saya bayar pajak tiap bulan kemudian tiap tahun juga laporan ke kantor pajak, tapi uang pajak yang saya bayarkan malah dipakai buat memperkaya pihak-pihak tertentu. Saya merasa ngapain bayar pajak hanya untuk memperkaya pihak-pihak tertentu di perpajakan, bukannya untuk membangun negara lebih baik. Tetapi kenyataannya makin banyak orang miskin, fasilitas dan prasarana yang rusak dan tidak layak". Sang informan juga mengakui adanya perubahan sikap, yang dulunya patuh, taat dan jujur dalam urusan perpajakan, sekarang menjadi lebih tidak patuh, taat dan jujur. Persepsi bahwa uang yang dibayarkan kepada negara tidak dipergunakan dengan benar yang membuat informan enggan untuk kembali patuh, taat dan jujur dalam urusan perpajakan. Kenyataan senada juga diakui oleh informan lain, “Jadi malas bayar pajak. Penghasilan ngak seberapa harus dipotong pajak, sedangkan orang yang nyata-nyata harus bayar pajak besar malah memanipulasi pajak tersebut. Sungguh tidak adil”.

\section{Pemahaman ketiga: Pajak, antara Negara dan Tuhan}

Pemahaman pertama dan kedua di atas menunjukkan betapa masyarakat pada umumnya dan Wajib Pajak pada khususnya, tidak mampu lagi mempercayai dunia perpajakan Indonesia. Begitu banyak manipulasi, intrik dan korupsi yang mewarnai wajah perpajakan Indonesia. Namun, tidak semua Wajib Pajak bersikap apatis dan tidak mau membayar pajak secara patuh, taat dan jujur. Mayoritas informan masih menyatakan kasus korupsi petugass pajak tidak mengubah kepatuhan, ketaatan dan kejujuran diri mereka dalam urusan perpajakan. Banyak faktor yang mendasari sikap para informan tersebut. Banyak di antara mereka yang menyatakan masih takut melanggar hukum dengan tidak melaporkan dan membayar pajak secara benar. Salah satu informan menyatakan "Saya tetap melaporkan dan membayar dengan sejujurjujurnya namun tentu sekarang harus semakin hati-hati apabila berurusan dengan perpajakan". Pendapat informan ini menunjukkan bahwa para informan masih mau patuh, taat dan jujur meskipun sudah tidak percaya lagi dengan lembaga perpajakan di Indonesia. Informan lain juga menyebutkan, "Kewajiban saya adalah tetap taat pajak kepada Negara". Pendapat ini menunjukkan masih adanya rasa cinta kepada Negara dan paling tidak diwujudkan dengan membayar pajak. Mau tidak mau, informan tetap harus membayar pajaknya dengan patuh, taat dan jujur meskipun persepsi mereka terhadap dunia perpajakan Indonesia telah menurun.

Kejujuran juga merupakan sebuah hal yang harus kita pertanggungjawabkan pada Tuhan, bukan kepada sesama manusia. Salah satu informan dengan yakin mengatakan, "Kasus korupsi memang tidak mempengaruhi ketaatan dan kejujuran saya dalam pembayaran pajak, karena jujur dan tidak jujur adalah urusan saya dengan Tuhan. Jadi saya taat bukan karena takut pada negara atau pegawai pajak, tetapi 
karena takut pada Tuhan". Persepsi buruk Wajib Pajak terhadap dunia perpajakan Indonesia belum mampu mengikis kejujuran Wajib Pajak karena relasi spiritual mereka dengan Tuhan. Keimanan seseorang juga menjadi patokan dalam ketaatan dan kejujurannya melaporkan dan membayar pajak. Meskipun informan memiliki persepsi yang buruk terhadap dunia perpajakan Indonesia, dengan didasari keimanan dan niat yang baik, maka ketaatan dan kejujuran Wajib Pajak masih terjaga.

Pajak adalah urusan individu Wajib Pajak dengan Negara dan juga Tuhan mereka. Wajib Pajak masih berusaha untuk berbakti kepada Negara meskipun tidak yakin dengan penggunaan pajak itu sendiri. Dalam hubungan yang lebih tinggi, Wajib Pajak melihat bahwa yang mereka lakukan berhubungan langsung dengan Sang Maha Tinggi, yaitu Tuhan. Kejujuran yang mereka junjung bukan untuk Negara ataupun petugas pajak. Pajak memang bagian dalam suatu Negara. Namun dalam ajaran-ajaran agama juga ditekankan masalah kejujuran yang salah satunya juga berbicara mengenai pajak. Mengutip Izza dan Hamzah (2009), salah satu teologi agama yang secara jelas berbicara tentang pajak adalah "Berikanlah kepada Kaisar apa yang wajib kamu berikan pada Kaisar dan kepada Allah apa yang wajib kamu berikan kepada Allah". Hal ini menunjukkan hubungan antara Pajak, Negara dan Tuhan yang mengakibatkan sebagian Wajib Pajak masih berusaha patuh, taat dan jujur dalam pelaksanaan urusan perpajakan.

\section{Mata Ketiga: Merangkul Setiap Pencarian dan Pemahaman}

Pencarian dan pemahaman telah dilalui. Selangkah demi selangkah dalam setapak demi setapak dalam jalan yang tidak mudah, pemahaman dicari, diamati dan pada akhirnya didalami. Pencarian awal dilakukan dengan menggunakan alat uji statistika, yaitu PLS. Dari hasil uji tersebut diketahui bahwa persepsi Wajib Pajak berpengaruh negatif terhadap ketaatan dan kejujuran Wajib Pajak secara signifikan. Artinya, semakin persepsi Wajib Pajak dipengaruhi kasus korupsi petugas pajak maka ketaatan dan kejujuran Wajib Pajak akan semakin rendah. Kondisi ini dijelaskan dengan nilai korelasi hubungan antara Persepsi Wajib Pajak kepada Ketaatan Wajib Pajak adalah sebesar -0,570. Korelasi hubungan antara Persepsi Wajib Pajak kepada Kejujuran Wajib Pajak adalah -0,729. Dengan melihat nilai T-Statistik, diperoleh hasil yang signifikan untuk masing-masing hubungan variabel karena dunia perpajakan Indonesia yang dinilai dari indicator variabel Ketaatan Wajib Pajak dan Kejujuran Wajib Pajak masing-masing memiliki nilai 6,557 dan 10,916 yang lebih besar dari 1,96.

Pencarian dilanjutkan pada usaha memahami fenomena yang terkandung di dalamnya. Fenomena korupsi petugas pajak yang "hidup" dan sensasional dalam masyarakat Indonesia tentu meninggalkan jejak-jejak ingatan dan persepsi dalam diri masyarakat dan Wajib Pajak. Melalui pendekatan fenomenologi, usaha untuk memahami menunjukkan sinar. Terdapat tiga pemahaman yang didalami dalam penelitian ini. Pemahaman pertama yang terurai adalah citra dunia perpajakan Indonesia ibarat sudah jatuh tertimpa tangga. Peribahasa tersebut sangat sesuai dengan kenyataan dunia perpajakan Indonesia. Kondisi dunia perpajakan yang sedang mencoba untuk merangkak dan berdiri, dijatuhkan kembali dengan fenomena kasus korupsi petugas pajak yang tentu menyeret nama-nama "teman" petugas pajak yang lain. Citra dunia perpajakan Indonesia dalam persepsi Wajib Pajak tidak mengalami perbaikan namun tentu mengalami kemunduran. 
Pemahaman kedua yang terekam adalah fenomena "Gayus Tambunan" membuka mata dan sikap. Sebelum kasus "Gayus Tambunan", "kebusukan" dunia perpajakan Indonesia masih tertutup rapat dan sulit terendus oleh masyarakat. Namun, kasus Gayus Tambunan dan korupsi-korupsi setelahnya telah mampu membuka mata Wajib Pajak terhadap fakta-fakta dan bukti terjadinya manipulasi, intrik serta korupsi di dunia perpajakan Indonesia. Fakta-fakta ini pula turut membangun sikap para Wajib Pajak dalam menunaikan urusan perpajakannya. Semakin banyak Wajib Pajak yang merasa malas dan enggan untuk membayar pajak apalagi secara taat dan jujur. Inilah pemahaman kedua yang mampu terekam dalam proses perjalanan. Pemahaman terakhir adalah Pajak, antara Negara dan Tuhan. Mayoritas Wajib Pajak memang memiliki persepsi yang buruk terhadap dunia perpajakan Indonesia, namun hal tersebut tidak mengubah perilaku mereka untuk patuh, taat dan jujur dalam urusan perpajakan. Perilaku ini muncul karena ketakutan mereka untuk melanggar hukum dengan tidak patuh, taat dan jujur dalam melaporkan dan membayar pajak. Dorongan dari para Wajib Pajak untuk tetap berbakti kepada Negara juga menjadi salah satu faktor tegaknya kepatuhan, ketaatan dan kejujuran Wajib Pajak. Lebih dari itu, Wajib Pajak juga merasa bahwa ketaatan dan kejujuran bukan hanya urusan dunia belaka namun lebih jauh mengarah kepada yang Maha Tinggi, yaitu Tuhan.

Pencarian dan pemahaman terangkul dan berjalan beriringan untuk menemukan makna yang terkadung dalam perjalanan ini. Dua langkah yang berbeda menyatu dalam jalan ketiga dan menemukan makna yang lebih mendalam. Pencarian dan pemahaman telah menemukan titik temu dan berangkul dalam memaknai hasil bersama. Berbagai pengertian yang muncul dalam diri Wajib Pajak adalah wujud refleksi dari persepsi yang mendalam dan diwujudkan dalam bentuk sikap.

\section{KESIMPULAN DAN SARAN}

Pencarian dan pemahaman telah bertemu dalam jalan ketiga. Hasil penelitian di atas menunjukkan adanya hubungan negatif antara persepsi Wajib Pajak dengan ketaatan dan kejujuran Wajib Pajak setelah kasus korupsi petugas pajak. Dari hasil pemahaman juga ditemukan adanya citra perpajakan Indonesia yang memang sudah buruk sebelum terjadinya kasus korupsi petugas pajak. Fakta yang terungkap dalam kasus korupsi petugas pajak juga telah mampu membuka mata para Wajib Pajak tentang buruknya sistem perpajakan di indonesia. Pemahaman terakhir menunjukkan di tengah buruknya persepsi Wajib Pajak terhadap dunia perpajakan Indonesia, dorongan untuk tetap berbakti kepada Negara dan mengikuti perintah Tuhan masih tetap dipegang oleh para Wajib Pajak.

Dalam usaha pencarian dan pemahaman masih banyak keterbatasan yang ditemui. Penelitian ini menfokuskan informan adalah Wajib Pajak Orang Pribadi dan bukan badan. Penelitian ini juga menggunakan jumlah informan dalam jumlah yang tidak besar, karena itu penelitian ini tidak dapat digeneralisasikan. Pengembangan penelitian ini masih sangat mungkin dilakukan, baik dari sisi informan, kuantitas maupun metode penelitian. Peneliti berharap pengembangan penelitian ini dapat dilakukan dalam usaha pengembangan ilmu pengetahuan. 


\section{TINJAUAN PUSTAKA}

Cahyani, L. P. G. \& Noviari, N. (2019). Pengaruh Tarif Pajak, Pemahaman Perpajakan dan Sanksi Perpajakan terhadap Kepatuhan Wajib Pajak UMKM. E-jurnal Akuntansi Universitas Udayana, 26(3), 1885-1911.

Djasmoredjo, B. D. M., (2004). Persepsi Karyawan Laki-Laki terhadap Pemimpin Perempuan Bersifat Lebih Asuh Daripada Pemimpin Laki-Laki. Jurnal Widya Manajemen \& Akuntansi, 4(3), 316-333

Hermansyah, W., Tarjo dan Herawati, N. (2009). Persepsi Wajib Pajak terhadap Sunset Policy. Simposium Nasional Akuntansi (SNA)-XII Palembang

Izza, I. A. N. dan Hamzah, A. (2009). Etika Penggelapan Pajak Perspektif Agama: Sebuah Studi Interpretatif. Simposium Nasional Akuntansi (SNA)-XII Palembang

Jogianto, H.M. dan Abdillah, W. (2009). Konsep \& Aplikasi PLS (Partial Least Square) untuk Penelitian Empiris. Yogyakarta: BPFE

Khairin, F. N. (2008). Independensi dan Conflict of Interest Auditor di KAP Ditinjau dari Perspektif Teori Konflik. Tesis Universitas Brawijaya: Malang

Lumbanrau, R. E. (2016). Rentetan Kasus Korupsi yang Menjerat Pegawai Pajak. https://m.cnnindonesia.com/nasional/20161122162351-12-174492/rentetankasus-korup-si-yang-menjerat-pegawai-pajak. 23 November 2019.

Mahfud, Arfan, M. \& Abdullah, S. (2017). Pengaruh Pemahaman Peraturan Perpajakan, Kesadaran Membayar Pajak dan Kualitas Pelayanan Perpajakan terhadap Kepatuhan Wajib Pajak Badan (Studi Empiris pada Koperasi di Kota Banda Aceh). Jurnal Magister Akuntansi Pascasarjana Universitas Syiah Kuala, 6(3), 1-9.

Mohammad, Y. (2018). Korupsi dan Pengkhianatan Petugas Pajak Ambon. Diunduh dari https://beritagar.id/artikel/berita/korupsi-dan-pengkhianatan-petugaspajak-ambon.

Moleong, L.J., (2005). Metodologi Penelitian Kualitatif. PT. Remaja Rosda Karya. Bandung

Raharjo, M. (2010). Triangulasi dalam Penelitian Kualitatif. www.mudjiaraharjo.com. 11 Januari 2011

Ramadhan, A. (2019). Bos Dealer Jaguar Suap Pegawai Pajak Rp 1,8 Miliar, 5 Orang Jadi Tersangka. Diunduh dari https:/ / nasional.kompas.com/read/2019/08/15/18032681/bos-dealer-jaguarsuap-pegawai-pajak-rp-18-miliar-5-orang-jadi-tersangka

Robbins, S. P., (2003). Organizational Behaviour. Tenth Edition. New Jersey: Prentice Hall Inc.

Susanti, M., Dewi, S. P. \& Sufiyati. (2017). Kepatuhan Pelaporan Wajib Pajak (Studi Kasus di Jakarta Barat dan Tangerang). Jurnal Bisnis dan Akuntansi, 19(2), 141156.

Sutopo, H.B. (2003). Pengumpulan dan Pengolahan Data Penelitian Kualitatif, Dalam Metodologi Penelitian Kualitatif; Tinjauan Teoritis dan Praktis, Lembaga Penelitian Universitas Islam Malang dan Visipress. Malang 
Tashakkori, A. dan Teddlie, C. (2010). Handbook of Mixed Methods. Yogyakarta: Pustaka Pelajar

Vionita \& Kristanto, S. B. (2018). Pengaruh Sosialisasi Perpajakan, Kesadaran Wajib Pajak dan Adanya Sanksi Pajak terhadap Kepatuhan Perpajakan bagi Prospective TaxPayer, Jurnal Akuntansi Kontemporer, 10(2), 81-91.

Wiyarni, Hartini \& Djuharni, D. (2018). Pengaruh Kompleksitas Peraturan Perpajakan, Kualitas Layanan, Sanksi Perpajakan dan Pemeriksaan terhadap Kepatuhan Pajak, Jurnal Akuntansi Kontemporer, 10(1), 14-23.

Yusro, H. W. \& Kiswanto. (2014). Pengaruh Tarif Pajak, Mekanisme Pembayaran Pajak dan Kesadaran Membayar Pajak Terhadap Kepatuhan Wajib Pajak UMKM di Kabupaten Jepara, Accounting Analysis Journal, 3(4), 429-436. 